\title{
Erratum to: High Methodologic Quality But Poor Applicability: Assessment of the AAOS Guidelines Using The AGREE II Instrument
}

Sanjeeve Sabharwal MBBS, MRCS, MSc,

Nirav K. Patel MBBS, MRCS, MSc, Salman Gauher MBBS, BSc,

Ian Holloway MBBS, FRCS (Orth), Thanos Athanasiou MD, PhD, FRCS, FETCS

Published online: 24 April 2014

(C) The Association of Bone and Joint Surgeons (B) 2014

\section{Erratum to: Clin Orthop Relat Res \\ DOI 10.1007/s11999-014-3530-0}

The last name of the last author was misspelled as Thanos Athansiou MD, PhD, FRCS, FETCS on the original publication. The correct spelling of his name is Thanos Athanasiou MD, PhD, FRCS, FETCS.

The authors apologize for this error.

The online version of the original article can be found under doi:10. 1007/s11999-014-3530-0.

S. Sabharwal ( $₫)$, N. K. Patel, T. Athanasiou Department of Surgery and Cancer, Imperial College, 10th Floor QEQM Building, St Mary's Hospital, London W2 1NY, UK e-mail: sanjeeve.sabharwal@ic.ac.uk

S. Gauher, I. Holloway

Department of Orthopaedic Surgery, The North West London

Hospitals NHS Trust, Northwick Park Hospital, Harrow, UK 